\title{
Biological effectiveness of the range of disinfectants winter wheat seeds used in Krasnodar Territory
}

\author{
Natalya Anatolyevna Moskaleva $^{1}$, Natalia Nikolaevna Dmitrenko ${ }^{1}$, and Natalya \\ Anatolyevna Sasova ${ }^{2}$ \\ ${ }^{1}$ FSBEI HE "Kuban State Agrarian University named after I.T. Trubilina", Kalinina str., 13, 350044 \\ Krasnodar, Russia \\ ${ }^{2}$ Branch of VGBU "Rosselkhoz" in the Krasnodar Territory, Rasshilevskaya str., 329, 350051 \\ Krasnodar, Russia
}

\begin{abstract}
In the conditions of the Krasnodar Territory, the pre-sowing treatment of seeds with drugs against diseases has firmly entered the system of protection of winter wheat. The use of seed dressing agents minimizes the risk of reducing field germination, ensures good overwintering of the crop, while being one of the most environmentally friendly plant protection methods. The idea of the biological efficiency of the seed disinfectants applied in the conditions of the region will allow not only to purposefully select a disinfectant, but also to prevent the resistance of pathogens causing diseases of seeds. An analysis of the range of fungicidal disinfectants used in the Krasnodar Territory in 2019 showed that the range was based on combined disinfectants based on several active substances with a different mechanism and spectrum of action, as well as that the shares of onecomponent and four-component drugs in it were - $10 \%$, two-component $20 \%$. Combined dressers based on three active ingredients were the basis of the range used, the share of such preparations was $60 \%$. Analysis of the data obtained allows to conclude that the modern range of dressing agents used in the farms of the Krasnodar Territory is capable of almost completely restraining the development of the pathogenic complex on winter wheat seeds. The maximum biological efficiency at the level of $100 \%$ was shown by the preparations in protection against dust and kernel smut, while it was at the level of $96.5 \%$ in protection against fusarium root rot.
\end{abstract}

\section{Introduction}

In the Russian Federation, a prerequisite for food security and independence is sustainable production of winter wheat grain, which ensures political and economic stability [9]. The Krasnodar Territory takes the leading place in the winter wheat grain harvesting. The soil and climatic conditions of the Krasnodar Territory allow to cultivate this crop in all agroclimatic zones of the region [1,6]. The annual sowing area of this crop in the region is 1.5-1.6 mln ha [2.4]. Crop losses caused by diseases amount to $15-35 \%$, of which $60 \%$ of losses occur due to poor-quality seed dressing [4,7]. In production, it is important to get not only healthy, but also even sprouts of winter wheat, which is currently almost impossible 
without pre-sowing seed treatment, since there are practically no healthy lots of seed grain, among which the most dangerous is the Fusarium genus fungi, both in Russia and abroad [10]. It is known that more than $60 \%$ of fungal phytopathogens are transmitted through winter wheat seeds [8]. In addition, there can be a large amount of pathogenic microflora of various etiologies [3] on plant residues on the surface of the soil or in its upper layer, therefore, seed dressing is of particular importance. This is a preventive measure against internal and external seed infection. In many farms of the Krasnodar Territory, pre-sowing treatment of seeds with drugs against diseases has become a part of the system of protection of winter wheat. The literature review showed that the use of seed dressing minimizes the risk of reducing field germination, provides a good overwintering of the crop, being at the same time one of the most environmentally safe plant protection methods.

The research was aimed to study the biological efficiency of the seed disinfectant range used in the Krasnodar Territory, considering the pathogenic complex of winter wheat seeds formed during the years of research. Following issues were considered in the course of research:

- weather conditions during the growing season of winter wheat in 2018-2019;

- study of the species composition of the pathogenic complex of winter wheat seeds of the 2019 harvest in the Krasnodar Territory;

- study of the efficiency of the applied range of winter wheat seed disinfectants in the conditions of the Krasnodar Territory

\section{Materials and methods}

Research on the topic was performed in the research laboratory of the Kuban State Agrarian University at the Department of Phytopathology, Entomology and Plant Protection and in the laboratory of the branch of the Federal State Budgetary Institution "Rosselkhoztsentr" in the Krasnodar Territory. An assessment of the infection with pathogenic fungi of winter wheat grain in the Krasnodar Territory of the 2019 harvest was performed. Winter wheat grain samples were taken from 35 districts of the Krasnodar Territory.

The method of centrifugation and subsequent microscopic examination of wash water were applied to determine kernel smut on seeds. When determining the infection of seeds with micromycete species, the visual method and the method of a wet chamber were used. Determination of the species composition of micromycetes was performed by microscopy.

The weather conditions were quite favorable for the winter wheat overwintering. The first half of May 2018 was warm and dry. Due to the increased temperature, the development of winter crops was accelerated. June was characterized by abnormally hot weather with frequent dry winds. Only in the third ten-day period, precipitation was of a stormy nature and was unevenly distributed over the territory of the region. The first half of May 2019 was warm and dry. Precipitation on some days was in the form of rain, with heavy and very heavy rains (locally). June was abnormally hot and dry, with only occasional thunderstorm rains. Weather conditions in June-early July for harvesting were generally good, but there were short breaks due to rains for 1-3 days. Such cumulative weather conditions influenced the formation of a complex of pathogens during the growing season of winter wheat.

The results of phytoexamination of seeds before sowing seeds in 2018 showed that there were practically no consignments of grain free from seed infection. Therefore, dressing winter wheat seeds before sowing in the conditions of the region is an important technique. The idea of the biological efficiency of the seed disinfectants applied in the conditions of the region will allow not only to purposefully select a disinfectant, but also to prevent the resistance of pathogens causing diseases of seeds.

The biological efficiency of seed dressing preparations is determined by various factors, the most important of which is the toxicity of the active substance for the pest. The modern 
range of preparations for treating seeds against diseases contains fungicides with a different spectrum of action and action on the harmful organism. Analysis of the range of fungicidal disinfectants used in the Krasnodar Territory in 2019 showed that it was based on combined disinfectants based on several active substances with a different mechanism and spectrum of action (table 1). [5]

Table 1. Biological efficiency of the seed disinfectant range used in the Krasnodar Territory, 2018 2019

\begin{tabular}{|c|c|c|c|c|c|}
\hline \multirow[b]{2}{*}{ Disinfectant } & \multirow{2}{*}{$\begin{array}{c}\text { Consumpti } \\
\text { on } \\
\text { of } \\
\text { preparatio } \\
\mathrm{n}, 1 / \mathrm{t}\end{array}$} & \multirow[b]{2}{*}{ Harmful object } & \multicolumn{3}{|c|}{ Biological efficiency, $\%$} \\
\hline & & & Medium & minimum & $\underset{\mathrm{m}}{\operatorname{maximu}}$ \\
\hline $\begin{array}{c}\text { Vibrans Integral, component } \\
\text { mixture }(175+25+25+10 \\
\mathrm{g} / \mathrm{l}) \\
\end{array}$ & 1.5 & root rot & 93.0 & 93.0 & 94.0 \\
\hline $\begin{array}{l}\text { Vial Trio, water suspension } \\
\text { concentrate }(5+30+120 \mathrm{~g} / \mathrm{l})\end{array}$ & 0.8 & $\begin{array}{c}\text { loose smut and } \\
\text { kernel smut }\end{array}$ & 100.0 & 100.0 & 100.0 \\
\hline $\begin{array}{l}\text { Vitalon, component mixture } \\
(400+14 \mathrm{~g} / 1)\end{array}$ & 2.0 & $\begin{array}{c}\text { loose smut, seeds } \\
\text { molding }\end{array}$ & 97.5 & 95.0 & 98.0 \\
\hline $\begin{array}{l}\text { Grandseal Ultra, component } \\
\text { mixture }(75+45+20 \mathrm{~g} / 1)\end{array}$ & 0.5 & fusarium rot & 85.0 & 83.0 & 85.3 \\
\hline $\begin{array}{l}\text { Divident Extreme, component } \\
\text { mixture }(92+23 \mathrm{~g} / 1)\end{array}$ & 0.6 & fusarium rot & 93.0 & 92.0 & 94.0 \\
\hline $\begin{array}{c}\text { Lamador Pro, component } \\
\text { mixture }(100+60+20 \mathrm{~g} / \mathrm{l})\end{array}$ & 0.5 & fusarium rot & 95.0 & 93.0 & 96.0 \\
\hline $\begin{array}{l}\text { Maxim Extreme, component } \\
\text { mixture }(18.7+6.25)\end{array}$ & 1.8 & $\begin{array}{c}\text { kernel and loose } \\
\text { smut }\end{array}$ & 100.0 & 100.0 & 100.0 \\
\hline $\begin{array}{c}\text { Polaris, ME }(100+25+25 \\
\mathrm{g} / 1)\end{array}$ & 1.5 & fusarium rot & 90.0 & 88.0 & 93.0 \\
\hline $\begin{array}{c}\text { Polaris, ME }(100+25+25 \\
\mathrm{g} / \mathrm{l})\end{array}$ & 1.5 & kernel smut & 100.0 & 100.0 & 100.0 \\
\hline $\begin{array}{l}\text { Celest Max, component } \\
\text { mixture }(125+25+15 \mathrm{~g} / 1)\end{array}$ & 1.5 & fusarium rot & 85.0 & 83.0 & 85.3 \\
\hline $\begin{array}{l}\text { Sistiva, component mixture } \\
(333 \mathrm{~g} / 1)\end{array}$ & 1.0 & kernel smut & 100.0 & 100.0 & 100.0 \\
\hline $\begin{array}{c}\text { Sistiva, component mixture } \\
(333 \mathrm{~g} / \mathrm{l})\end{array}$ & 1.0 & fusarium rot & 95.0 & 93.0 & 96.5 \\
\hline $\begin{array}{l}\text { Triaktiv, component mixture } \\
(100+120+40 \mathrm{~g} / 1)\end{array}$ & 0.30 & $\begin{array}{c}\text { loose and kernel } \\
\text { smut }\end{array}$ & 100.0 & 100.0 & 100.0 \\
\hline
\end{tabular}

At the same time, the share of one-component and four-component drugs in it was - $10 \%$, two-component $-20 \%$. Combined dressers based on three active ingredients were the basis of the range used, the share of such preparations was $60 \%$.

The biological efficiency of dressing preparations is also determined by such indicators as the degree of seed surface coverage and the concentration of the dressing, agro-climatic conditions, the correct choice of dressing based on the results of phytoexamination (Table 2) [5] 
Table 2. Biological efficiency of the applied seed disinfectant range in the Krasnodar Territory, 2019

\begin{tabular}{|c|c|c|c|c|c|}
\hline \multirow[b]{2}{*}{ Disinfectant } & \multirow{2}{*}{$\begin{array}{c}\text { Consu } \\
\text { mption } \\
\text { of } \\
\text { prepar } \\
\text { ation, } \\
1 / \mathrm{t}\end{array}$} & \multirow[b]{2}{*}{ Harmful object } & \multicolumn{3}{|c|}{ Biological efficiency, $\%$} \\
\hline & & & Medium & $\underset{\mathrm{m}}{\operatorname{minimu}}$ & $\underset{\mathrm{m}}{\operatorname{maximu}}$ \\
\hline $\begin{array}{l}\text { Vibrans Integral, component } \\
\text { mixture }(175+25+25+10 \\
\mathrm{g} / \mathrm{l})\end{array}$ & 1.5 & root rot & 93.0 & 93.0 & 94.0 \\
\hline $\begin{array}{l}\text { Vial Trio, water suspension } \\
\text { concentrate }(5+30+120 \mathrm{~g} / \mathrm{l})\end{array}$ & 0.8 & loose and kernel smut & 100.0 & 100.0 & 100.0 \\
\hline $\begin{array}{l}\text { Vitalon, component mixture } \\
(400+14 \mathrm{~g} / 1)\end{array}$ & 2.0 & loose smut seed molding & 97.5 & 95.0 & 98.0 \\
\hline $\begin{array}{l}\text { Grandseal Ultra, component } \\
\text { mixture }(75+45+20 \mathrm{~g} / 1)\end{array}$ & 0.5 & fusarium rot & 85.0 & 83.0 & 85.3 \\
\hline $\begin{array}{l}\text { Divident Extreme, component } \\
\text { mixture }(92+23 \mathrm{~g} / \mathrm{l})\end{array}$ & 0.6 & fusarium rot & 93.0 & 92.0 & 94.0 \\
\hline $\begin{array}{l}\text { Lamador Pro, component } \\
\text { mixture }(100+60+20 \mathrm{~g} / \mathrm{l})\end{array}$ & 0.5 & fusarium rot & 95.0 & 93.0 & 96.0 \\
\hline $\begin{array}{c}\text { Maxim Extreme, component } \\
\text { mixture }(18.7+6.25)\end{array}$ & 1.8 & kernel and loose smut & 100.0 & 100.0 & 100.0 \\
\hline $\begin{array}{c}\text { Polaris, ME }(100+25+25 \\
\mathrm{g} / \mathrm{l})\end{array}$ & 1.5 & fusarium rot & 90.0 & 88.0 & 93.0 \\
\hline $\begin{array}{c}\text { Polaris, ME }(100+25+25 \\
\mathrm{g} / \mathrm{l})\end{array}$ & 1.5 & kernel smut & 100.0 & 100.0 & 100.0 \\
\hline $\begin{array}{l}\text { Celest Max, component } \\
\text { mixture }(125+25+15 \mathrm{~g} / \mathrm{l})\end{array}$ & 1.5 & fusarium rot & 85.0 & 83.0 & 85.3 \\
\hline $\begin{array}{l}\text { Sistiva, component mixture } \\
(333 \mathrm{~g} / 1)\end{array}$ & 1.0 & kernel smut & 100.0 & 100.0 & 100.0 \\
\hline $\begin{array}{l}\text { Sistiva, component mixture } \\
(333 \mathrm{~g} / 1)\end{array}$ & 1.0 & fusarium rot & 95.0 & 93.0 & 96.5 \\
\hline $\begin{array}{c}\text { Triaktiv, component mixture } \\
(100+120+40 \mathrm{~g} / \mathrm{l})\end{array}$ & 0.30 & loose and kernel smut & 100.0 & 100.0 & 100.0 \\
\hline
\end{tabular}

The analysis of the data obtained allows us to conclude that the modern range of dressing agents used in the farms of the Krasnodar Territory is capable of almost completely restraining the development of the pathogenic complex on winter wheat seeds. The maximum biological efficiency at the level of $100 \%$ was shown by the preparations in the protection against dust and kernel smut, and in the protection against fusarium root rot at the level of $96.5 \%$.

It should be noted that the severity of the pathogenic complex remained at a low level for the last two years due to weather conditions (dry and hot weather prevailed in most of the territory of the region). However, the ubiquitous high infectious stock in the soil and with abundant precipitation during flowering and earing of winter crops increases the possibility of epiphytotic damage to winter wheat; therefore, sowing untreated seeds creates conditions for the accumulation of infection.

Pursuant to the information and analytical center of GBU KK "Kuban Agricultural ICC", if in 2018 out of the required 180.51 th $\mathrm{t}$ in fact, 168.02 thousand tons were pickled, which amounted to $93 \%$ of grain, then in 2019 this figure decreased and of the required 170.77 thousand tons, 144.76 thousand tons were actually pickled, which amounted to $85 \%$ of the sown grain. A decrease in the volume or quality of dressing leads to a deterioration in the 
phytosanitary situation and the creation of foci of infection, causing contamination of the grain of the new harvest. Thus, pursuant to the phytoexamination, a positive trend was noted in the spread of diseases of seeds of the winter wheat crop in 2019 (Figure 1).

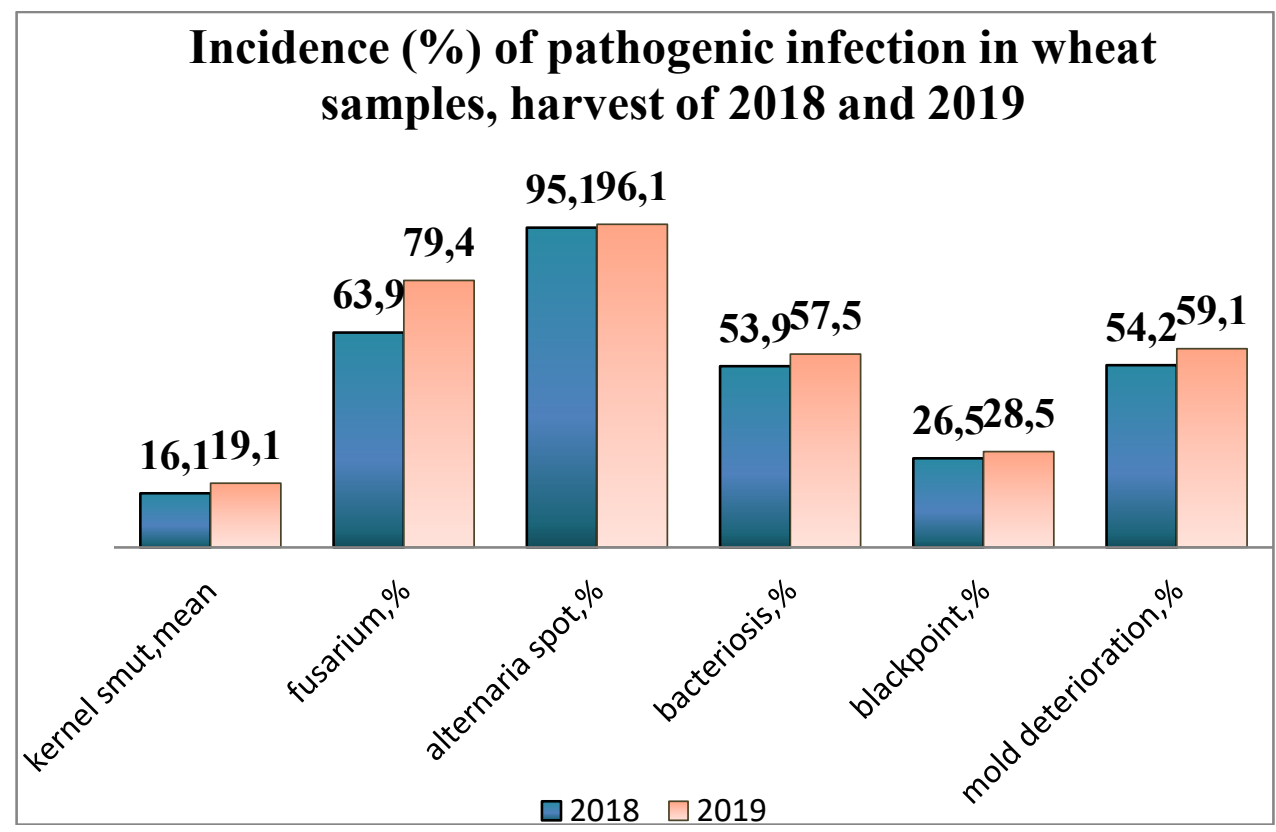

Fig. 1. Dynamics of damage to winter wheat seeds during phytoexamination in 2018 and 2019, Krasnodar Territory (Federal State Budgetary Institution "Rosselkhoztsentr" in Krasnodar Territory).

Thus, it can be argued that seed dressing is an important method in plant protection. A wide range of effective dressing agents is used in the region, $90 \%$ of which are combined. However, the full implementation of the protective effect of the drugs and making a decision on the advisability of dressing would require the following: the information about the place of winter wheat in the crop rotation and about the phytosanitary situation in the fields in the current year; forecasting the development and spread of diseases for the next year; the phytopathological examination report on the composition of the pathogenic complex of pathogens and the degree of infection of the seed material.

\section{Conclusion}

Phytoexamination of winter wheat seeds of the harvest of 2018 and 2019 from 35 districts of the Krasnodar Territory showed that the pathogenic microflora of grain was represented by: (Alternaria spp.), Hard smut (Tilletia tritici), fusarium (Fusarium graminearum etc..), mold (Aspergillus spp. and Penicillium spp.) and bacterioses (Pseudomonas spp., Xanthomonas spp.) and black embryo (Alternaria alternata).

The results of grain analysis of the harvest in 2018 showed a dominant position in the mycobiota of seeds of representatives of the genus Alternaria spp. Alternaria was observed in $97.4 \%$ of seed lots. Fungi of this genus had the highest frequency of occurrence on seeds from 55.9 to $72.0 \%$. Infected seeds of kernel smut (Tilletia tritici) were noted in $17.2 \%$, lots, with fusarium (Fusarium graminearum etc..) - $67.5 \%$ of lots, mold and bacteriosis - from $50.1 \%$ to $53.2 \%$ of seed lots and black embryo $-24.2 \%$ of seed lots. 
In the grain harvest in 2019 in the region, Alternaria was noted in $92.2 \%$ of seed lots, kernel smut in $17.4 \%$ of lots, Fusarium infected $-72.3 \%$. the weighted average percentage of infected seeds at the edge ranged from 14.5 to $18.3 \%$, which is higher than the 2018 level.

Infection of grain with Fusarium infection increased and was noted in $79.4 \%$ of the samples (the frequency of occurrence on average along the edge was $14.2 \%$ of the total number of infected seeds, the weighted average percentage of infection in the samples varied from 1.5 to $5.6 \%$ ). In 2019 , the infestation by saprophytic molds and bacteriosis increased in comparison with 2018.

A wide range of effective dressing agents is used in the region, $90 \%$ of which are combined. The disinfectants show high biological efficiency against a complex of smut diseases at the level of $99 \ldots 100 \%$, root rot, including fusarium infection (biological efficiency -89 ... 92\%).

\section{References}

1. A.A. Goncharenko, Bulletin of the Russian Agricultural Academy, 6, 49 (2005)

2. K.N. Gorpinchenko, Economy of agricultural and processing enterprises, 4, 46 (2012)

3. M.I. Zazimko, V.Yu. Buzko, P.V. Sidac et al., Plant protection and quarantine, 9, 19 (2013)

4. A.N. Korobko, The farming system of the Krasnodar Territory on an agrolandscape basis, 352 (2015)

5. Review of the phytosanitary state of agricultural crops in the Krasnodar Territory in 2019 and the forecast of the development of harmful objects in 2020, 108 (2020)

6. E. A. Pikushova, L. A. Shadrina et al., Agroecological monitoring in agriculture of the Krasnodar Territory, 431 (459), 82 (2008)

7. Ye.Yu. Toropova, Plant protection and quarantine, 2, 3 (2018)

8. V.A. Chulkina, Ye.Yu. Toropova, Plant protection and quarantine, 2, 21 (2007)

9. N.N. Dmitrenko, A.A. Karpenko, V.A. Kurylenko, Proceedings of the Kuban State Agrarian University, 2(77), 84 (2019)

10. A.N. Freije, K.A. Wise, Crop Protection, 77, 139 (2015) 